\title{
FAKTOR PENENTU PENGAMBILAN KEPUTUSAN PEMENUHAN KEBUTUHAN NUTRISI IBU HAMIL ANEMIA GIZI
}

\author{
Susi Endrawati, Tri Suwarni
}

\author{
Program Studi DIII Farmasi, Program Studi DIII Kebidanan \\ Poltekkes Bhakti Mulia Sukoharjo \\ Email: susiendrawati5@gmail.com
}

\begin{abstract}
Objective Research to determine the factors that influence the decision-making simultaneously to fulfilling the nutritional needs of pregnant women anemia and the percentage of each factor, the views of factors: 1) knowledge / supply of nutrients; 2) the influence of culture / customs; 3) the economy; 4) support the family; and 5) decision-making.

The study population was maternal anemia at four health centers working area of District Sukoharjo, using random sampling techniques and non-random sampling / non-probability sampling (samples are not random), using questionnaires and interviews. The results were analyzed with One Way Anova, multiple linear regression (multiple linear regretion), and Tukey HSD test Hoct Post / Post Hoct Bonfeeron.

Result Analysis of One Way Anova in four health centers, the value of (p) $0.000<0.05$, which means there is simultaneously a significant influence, and which factors influence the Tukey HSD test Hoct Post / Post Hoct Bonfeeroni.

The study concluded there was a significant influence on the decision-making factors fifth meeting nutritional needs of pregnant women anemia, namely: 1) the factors of knowledge / supply of nutrients ( health center Nguter $61.67 \%, 54.31 \%$ Sukoharjo, Tawangsari $51.67 \%$, Weru 27.78\%); 2) factors influence of culture / customs ( health center Tawangsari 37.5\%, Nguter 34.17\%, 25.86\% Sukoharjo, Weru 20.37\%); 3) factors economy ( health center Weru $48.15 \%$, Tawangsari $43.33 \%$, 39.66\% Sukoharjo, Nguter 30\%); 4) factor family support (health center Weru 36.29\%, Nguter 34.67\%, 33.79\% Sukoharjo, Tawangsari 33.33\%) and 5) factors decision making (health center Tawangsari 70\%, Sukoharjo 50.58\%, Weru $49.38 \%$ and $34.45 \%$ Nguter.
\end{abstract}

Key Words: Decisions, Nutrition, Pregnancy, Nutritional Anemia

\section{PENDAHULUAN}

Pada kasus tingginya angka kematian ibu melahirkan dan bayi, persentase terbesar cenderung disebabkan karena anemia gizi pada ibu semasa hamil. Menurut konsep (Husaini, 1989 et Kusumawati C, 2012) anemia gizi disebabkan oleh karena tidak tersedianya zatzat gizi dalam tubuh yang berperan dalam pembentukan sel darah merah. Zat-zat kimia tidak selamanya berpengaruh buruk pada tubuh manusia, kurangnya beberapa zat-zat tersebut dalam tubuh akan menyebabkan hemopoesis, misalnya; protein, vitamin, (asam folat, vitamin $\mathrm{B} 12$, vitamin $\mathrm{C}$ dan vitamin $\mathrm{E}$ ) dan mineral (Fe dan $\mathrm{Cu}$ ). Pada sekian banyak penyebab, yang paling menonjol menimbulkan hambatan hemopoesis adalah kekurangan zat besi, asam folat, dan vitamin B12, namun karena kekurangan asam folat dan vitamin B12 jarang ditemukan pada masyarakat, maka anemia gizi selalu dikaitkan sebagai anemia kurang zat besi. Anemia gizi yang terjadi pada ibu hamil akan berdampak pada ibu dan bayinya, dampak yang timbul antara lain, kehamilan abortus, berat bayi lahir rendah, kelahiran prematur, Intra Uterine growth retardation (IUGR), power tenaga saat melahirkan lemah sehingga menyebabkan persalinan menjadi lama, proses lamanya persalinan dapat meningkatkan angka infeksi pada ibu dan bayi, atonia uteri (uterus tidak bisa mengkerut) merupakan penyebab terjadinya perdarahan pada saat melahirkan maupun setelah melahirkan. Infeksi dan perdarahan merupakan faktor utama penyebab kematian ibu bersalin. Gejala umum yang dialami, kekelahan, pusing, pingsan, sering berdebar-debar, atau tampak pucat. Ibu hamil dikatakan anemia bila kadar hemoglobin atau darah merahnya kurang dari $11,00 \mathrm{~g} / \mathrm{dl}$.

Menurut Word Health Organzsation (WHO, 2008) anemia pada ibu hamil adalah kondisi ibu dengan kadar $\mathrm{Hb}<11 \mathrm{~g} / \mathrm{dl}$, Anemia pada ibu hamil di Indonesia sangat bervariasi, yaitu: Tidak anemia: $\mathrm{Hb}>11 \mathrm{~g} / \mathrm{dl}$, Anemia ringan: $\mathrm{Hb}$ 9-10.9 g/dl, Anemia sedang: $\mathrm{Hb} 7$ $8.9 \mathrm{~g} / \mathrm{dl}$, Anemia berat: $\mathrm{Hb}<7 \mathrm{~g} / \mathrm{dl}$ (Depkes, 2005). Jenis anemia yang sering terjadi adalah anemia defisiensi zat besi, dan kondisi ini 
mempengaruhi sekitar $15-25 \%$ ibu hamil dan berkontribusi sebesar $40 \%$ sebagai penyebab kematian ibu dan kelahiran prematur. Faktorfaktor tersebut diantaranya disebabkan karena kurangnya pengetahuan ibu hamil tentang nutrisi, pengaruh budaya berpantang makanan, ketidakmampuan dalam memenuhi kebutuhan nutrisi, serta kurangnya dukungan dari keluarga yang mempengaruhi ibu hamil dalam mengambil keputusan untuk memenuhi kebutuhan nutrisi selama kehamilan.

Kebudayaan suatu masyarakat mempunyai kekuatan yang cukup besar untuk mempengaruhi seseorang dalam memilih dan mengolah pangan yang akan dikonsumsi. Kebudayaan menuntun orang dalam cara bertingkah laku dan memenuhi kebutuhan dasar biologisnya termasuk kebutuhan terhadap pangan. Pada banyak masyarakat, usia atau kondisi seseorang dapat dipakai sebagai alasan untuk melarang makanan-makanan tertentu, sebagai contoh, permasalahan gizi pada ibu hamil di Indonesia tidak terlepas dari faktor budaya setempat. Hal ini disebabkan karena adanya kepercayaan-kepercayaan dan pantangan-pantangan terhadap beberapa makanan. Penelitian yang dilakukan Alwi dan Ratih di Papua dalam Hartati menyatakan bahwa terdapat pantangan makanan (dietary taboos) pada wanita hamil, seperti ikan yang akan menyebabkan ASI amis dan beberapa jenis buah, yaitu nenas, ketimun, pisang yang dianggap dapat menurunkan libido wanita. Rumusan Masalah: 1) Faktor-faktor apakah yang mempengaruhi secara simultan terhadap pengambilan keputusan pemenuhan kebutuhan nutrisi ibu hamil anemia gizi?, 2) Berapakah prosentase pengaruh masing-masing faktor, dilihat dari faktor pengetahuan/penyediaan nutrisi adekuat, pengaruh budaya/adat, faktor ekonomi, dukungan keluarga dan pengambilan keputusan.

\section{METODOLOGI PENELITIAN}

\section{Tempat dan Waktu Penelitian}

Penelitian dilakukan di wilayah kerja Dinas Kesehatan Kabupaten Sukoharjo. Pemilihan tempat didasarkan atas target 4 wilayah puskesmas desa maupun kota, yaitu Puskesmas Tawangsari, Puskesmas Weru, Puskesmas Nguter dan Puskesmas Sukoharjo. Waktu penelitian dilaksanakan pada bulan Maret 2016 sampai dengan Mei 2016. Data penelitian yang diambil adalah ibu hamil anemia gizi bulan Januari sampai dengan Mei 2016.

\section{Model dan Desain Penelitian}

Penelitian ini merupakan penelitian kuantitatif. Desain yang digunakan adalah observasional analitik, yaitu untuk mencari hubungan antara variabel bebas dan variabel terikat. Pengambilan data terhadap variabel penelitian menggunakan pendekatan cross sectional, dimana pengambilan data beberapa variabel penelitian dilakukan pada satu waktu (Dharma K, 2011).

\section{Populasi dan Sampel}

Populasi terjangkau sampel dalam penelitian ini adalah ibu hamil yang ada di wilayah kerja Dinas Kabupaten Sukoharjo di 4 Puskesmas kurang lebih 1308 orang. Populasi target dari pengambilan sampel Random dan purposiv sampling terwakili oleh 110 orang ibu hamil anemia gizi, terdiri dari Puskesmas Nguter (20 orang), Puskesmas Sukoharjo (40 orang), Puskesmas Weru (35 orang), Puskesmas Tawangsari (15 orang). Puskesmas Tawangsari. Sampel adalah ibu hamil anemia gizi dengan kriteria nilai $\mathrm{Hb}<11,0 \mathrm{~g} / \mathrm{dl}$. Teknik sampling yang digunakan adalah random sampling. Teknik Random sampling diambil dari kelas ibu hamil yang dilakukan di desa-desa binaan puskesmas Nguter, Sukoharjo, Weru, dan Tawangsari, yang dilaksanakan pada bulan Maret sampai dengan Mei pada minggu pertama/kedua Dalam 1 puskesmas diambil sampling 4 desa, sehingga untuk 4 puskesmas terwakili 16 desa. Penentuan jumlah sampel menggunakan rumus perhitungan sampel minimal dari Notoatmojo (2010) sebagai berikut:

\section{Keterangan:}

n: Jumlah sampel

$\mathrm{N}$ : Jumlah populasi

d: Tingkat kepercayaan yang digunakan (95\%)

Dengan demikian, jumlah sampel minimal dalam penelitian ini dengan jumlah populasi terjangkau sebanyak $110 \mathrm{ibu}$ hamil anemia gizi adalah sebagai berikut: 
$n=\frac{110}{1+110\left(0.05^{2}\right)}=86 \mathrm{Ibu}$ hamil anemia gizi

Teknik pengambilan sampling yang lain dengan menggunakan nonrandom/nonprobability sampling (sampel tidak acak) jenis purpos sampling (Notoatmodjo, 2010). Teknik non-random/non-probability sampling adalah pengambilan sampel yang dilakukan peneliti tidak secara acak namun pengambilan sampel diambil berdasarkan pada kriteria inklusi sampel yang telah ditentukan oleh peneliti sesuai dengan tujuan penelitian. Untuk pengambilan data purposive random sampling, diambil dari data puskesmas dan bidan desa, dimana kriteria sampel yang dipilih sudah ditentukan, yaitu ibu hamil anamia gizi dengan kriteria nilai $\mathrm{Hb}<11,0 \mathrm{~g} / \mathrm{dl}$ bulan Januari dan Februari. Teknik pengambilan sampel secara purposive sampling terwakili oleh 6 sampai 10 desa. Kriteria inkulusi dalam penelitian ini meliputi: (1) wanita hamil trimester 1,2,3, (2) terdiagnosa anemia dengan nilai $\mathrm{Hb}<11,0 \mathrm{~g} / \mathrm{dl}$ dalam waktu 1 bulan terakhir sebelum pengumpulan data, (3) penduduk asli, (4) berdomisili di wilayah Kecamatan Sukoharjo: Tawangsari, Weru, Nguter, Sukoharjo, dan (5) bersedia menjadi responden dalam penelitian ini.

\section{Uji Coba Instrumen Penelitian}

Instrumen yang digunakan dalam suatu penelitian ini adalah angket dan wawancara. Instrumen yang baik adalah instrumen yang valid dan reliabel. Oleh karena itu, sebelum instrument digunakan perlu diujicobakan terlebih dahulu untuk mengetahui validitas dan reliabilitasnya.

\section{Uji Validitas}

Validitas berasal dari kata validity yang mempunyai arti sejauh mana ketepatan dan kecermatan suatu instrument pengukur (tes) dalam melakukan fungsi ukurnya. Suatu tes dapat dikatakan mempunyai validitas yang tinggi apabila tes tersebut menjalankan fungsi ukurnya, atau memberikan hasil ukur yang tepat dan akurat sesuai dengan maksud dan tujuan digunakannya tes tersebut. Suatu tes menghasilkan data yang tidak relevan dalam pengukuran, dikatakan sebagai tes yang memiliki validitas rendah. Sisi lain yang sangat penting dalam konsep validitas adalah kecermatan pengukuran. Suatu tes yang validitasnya tinggi tidak saja akan menjalankan fungsi ukurnya dengan tepat akan tetapi juga dengan kecermatan tinggi, yaitu kecermatan dalam mendeteksi perbedaan - perbedaan kecil yang ada pada atribut yang diukurnya.

Rumus yang dipakai untuk mengetahui koefisien validitas adalah formula Gregory dimana diperlukan 2 panelis untuk memeriksa kecocokan antara indikator dengan butir-butir instrumen, dalam bentuk menilai relevan atau kurang relevan masing-masing indikator butir bila dicocokkan dengan butir-butirnya.

Formula Gregory adalah sebagai berikut:

$$
\text { Content Validity }(\mathrm{CV})=\frac{D}{A+B+C+D}
$$

Keterangan:

A: Jumlah item yang kurang relevan menurut kedua panelis

B: Jumlah item yang kurang relevan menurut panelis I dan relevan menurut panelis II

C: Jumlah item relevan menurut panelis I dan kurang relevan menurut panelis II

D: Jumlah item relevan menurut kedua panelis

Kriteria yang digunakan adalah jika $\mathrm{CV}>0,700$ maka analisis dapat dilanjutkan (Gregory, 2007).

Validitas penilaian angket.

Perhitungan validitas butir soal untuk penilaian angket menggunakan rumus korelasi Product Moment dari Pearson dengan rumus sebagai berikut:

$r_{x y}=\frac{N \sum X Y-\left(\sum X\right)\left(\sum Y\right)}{\sqrt{\left\{N \sum X^{2}-\left(\sum X\right)^{2}\right\}\left\{N \sum Y^{2}-\left(\sum Y\right)^{2}\right\}}}$

Keterangan:

rxy: koefisien korelasi suatu butir soal (koefisien validitas)

$\mathrm{X}$ : hasil pengukuran suatu tes yang ditentukan validitasnya

$\mathrm{Y}$ : kriteria yang dipakai

$\mathrm{N}$ : jumlah subyek (Arikunto, 2005)

Kriteria pengujian: Kriteria item dinyatakan valid jika rxy $>r$ tabel dan dinyatakan tidak valid jika rxy $\leq \mathrm{r}$ tabel 


\section{Uji Reliabilitas}

Pada instrumen angket, untuk menghitung koefisien reliabilitas menggunakan rumus alpha (digunakan untuk mencari reliabilitas yang skornya bukan 1 atau 0 ) yaitu sebagai berikut:

$$
\mathrm{r}_{\mathrm{tt}}=\alpha=\left(\frac{\mathrm{N}}{\mathrm{N}-1}\right)\left(1-\frac{\sum \mathrm{S}_{\mathrm{t}}^{2}}{\mathrm{~S}_{\mathrm{t}}^{2}}\right)
$$

Dengan:

$$
\mathrm{S}_{\mathrm{t}}=\frac{1}{\mathrm{~N}} \sqrt{\mathrm{N} \Sigma \mathrm{x}^{2}-(\Sigma \mathrm{X})^{2}}
$$

Keterangan:

Rtt : koefisien reliabilitas instrumen

$\mathrm{N}$ : banyaknya butir pertanyaan atau banyaknya soal

$\Sigma$ Si2 : jumlah kuadrat S tiap-tiap item

St2 : kuadrat dari S total keseluruhan item

Kriteria reliabilitas adalah sebagai berikut:

$0,91-1,00$

$0,71-0,90$

$0,41-0,70$

$0,21-0,40$

Negatif $-0,20$

(Arikunto, 2005:100-101)

\section{Uji Statistik}

Uji statistik yang digunakan dalam penelitian ini meliputi beberapa tahapan sebagai berikut:

a) Analisis univariat dilakukan dengan menjelaskan atau mendeskripsikan karakteristik responden. Dilakukan penyajian analisis deskriptif data katagorik dalam bentuk tabel yang terdiri dari distribusi frekuensi/jumlah dengan ukuran persentase/proporsi.

b) Analisis bivariat dilakukan untuk mengetahui hubungan antara variabel independen yaitu faktor-faktor yang mempengaruhi pengambilan keputusan pemenuhan kebutuhan nutrisi pada ibu hamil anemia gizi. Apakah variabel tersebut mempunyai hubungan yang signifikan atau hanya hubungan secara kebetulan. Dalam analisis uji statistik yang digunakan bisa memakai uji chi-square $\left(\mathrm{X}^{2}\right)$, uji $t$-test atau uji korelasi tergantung jenis data yang digunakan. Tingkat kemaknaan yang digunakan adalah 5\% ( $\alpha$ $=0,05)$ dengan nilai Confidence interval yang ditetapkan adalah $95 \%$

c) Analisis multivariat pada penelitian ini menggunakan analisis uji statistik regresi logistic karena menganalisis hubungan beberapa variabel independen yaitu faktorfaktor yang mempengaruhi pengambilan keputusan (faktor pengetahuan terkait : Rendah (R) kebutuhan nutrisi ibu hamil anemia gizi, faktor budaya/adat, faktor ekonomi dalam menyediakan nutrisi adekuat selama kehamilan, faktor dukungan keluarga, dan faktor dominan dalam pengambilan keputusan dalam keluarga).

d) Uji faktor secara simultan dengan menggunakan Uji One Way Anova dilanjutkan dengan Uji Post Hoc Test Tukey HSD atau Post Hoc Test Bonferroni untuk mengetahui pengaruh masingmasing indikator. 


\begin{tabular}{|c|c|c|c|c|}
\hline No. & Variabel & Alat \& Cara Ukur & Hasil Ukur & Skala \\
\hline 7 & $\begin{array}{l}\text { Pengetahuan } \\
\text { Nutrisi }\end{array}$ & $\begin{array}{l}\text { Adalah Pengetahuan, } \\
\text { pemahanan, sikap dan } \\
\text { tindakan nyata ibu hamil } \\
\text { tentang pemenuhan nutrisi } \\
\text { masa hamil }\end{array}$ & $\begin{array}{l}\text { Angket dan } \\
\text { wawancara }\end{array}$ & $\begin{array}{l}\text { Skala likert } \\
1 \text { sampai } 4 \\
1=(-) \\
4=(+)\end{array}$ \\
\hline 8 & $\begin{array}{l}\text { Pengaruh } \\
\text { budaya/adat }\end{array}$ & $\begin{array}{l}\text { Adalah Sikap, ataupun } \\
\text { tindakan ibu hamil dalam } \\
\text { merespon makanan ataupun } \\
\text { nutrisi,termasuk menikah } \\
\text { diusia muda, jarak } \\
\text { kehamilan yang terlalu } \\
\text { dekat, yang berhubungan } \\
\text { dengan kebiasaan, } \\
\text { adat/etnik/budaya } \\
\text { leluhur/nenek moyang. }\end{array}$ & $\begin{array}{l}\text { Angket dan } \\
\text { wawancara }\end{array}$ & $\begin{array}{l}\text { Skala likert } \\
1 \text { sampai } 4 \\
1=(-) \\
4=(+)\end{array}$ \\
\hline 9 & $\begin{array}{l}\text { Faktor } \\
\text { Ekonon }\end{array}$ & $\begin{array}{l}\text { Adalah sejumlah uang \& } \\
\text { atau barang yang dinilai } \\
\text { dengan uang yang dapat } \\
\text { digunakan keluarga selama } 1 \\
\text { bulan untuk pangan \& non } \\
\text { pangan. }\end{array}$ & $\begin{array}{l}\text { Angket dan } \\
\text { wawancara }\end{array}$ & $\begin{array}{l}\text { Skala likert } \\
1 \text { sampai } 4 \\
1=(-) \\
4=(+)\end{array}$ \\
\hline 10 & $\begin{array}{l}\text { Dukungan } \\
\text { keluarga/peran } \\
\text { suami }\end{array}$ & $\begin{array}{l}\text { Adalah dukungan keluarga } \\
\text { terhadap penyediaan nutrisi } \\
\text { adekuat, dan bentuk } \\
\text { perhatian perilaku nyata } \\
\text { keluarga dalam mendukung } \\
\text { masa kehamilan ibu }\end{array}$ & $\begin{array}{l}\text { Angket dan } \\
\text { wawancara }\end{array}$ & $\begin{array}{l}\text { Skala likert } \\
1 \text { sampai } 4 \\
1=(-) \\
4=(+)\end{array}$ \\
\hline 11 & $\begin{array}{l}\text { Pengambilan } \\
\text { keputusan }\end{array}$ & $\begin{array}{l}\text { Adalah suatu tindakan } \\
\text { nyata yang berpengaruh } \\
\text { pada ibu hamil dalam } \\
\text { memenuhi kebutuhan } \\
\text { nutrisi yang dikarenakan } \\
\text { faktor ekternal individu }\end{array}$ & $\begin{array}{l}\text { Angket dan } \\
\text { wawancara }\end{array}$ & $\begin{array}{l}\text { Skala likert } \\
1 \text { sampai } 4 \\
1=(-) \\
4=(+)\end{array}$ \\
\hline
\end{tabular}

\section{HASIL DAN PEMBAHASAN}

Uji Coba/ Tryout dilakukan di wilayah pukesmas Nguter yaitu di desa Kedung Winong dan desa Nguter pada kegiatan kelas ibu hamil, dengan jumlah responden 20.

Hasil perhitungan validitas dari kedua validator disajikan dalam Tabel 2.

Tabel 2. Hasil Validitas Instrumen oleh Tim Ahli

\begin{tabular}{ccccccc}
\hline $\begin{array}{c}\text { Jenis } \\
\text { Instrumen }\end{array}$ & A & B & C & D & CV & Kesimpulan \\
\hline Angket & 2 & 2 & 2 & 25 & 0.80 & $\begin{array}{c}\text { dapat } \\
\text { dilanjutkan }\end{array}$ \\
\hline
\end{tabular}

Hasil validitas oleh tim ahli, untuk semua intrumen angket dapat dilanjutkan, tetapi beberapa instrumen soal tersebut harus direvisi terlebih dahulu, sesuai dengan masukan dan saran yang diberikan oleh validator, dikarenakan ada beberapa soal angket yang mempunyai bahasa rancu/kurang dimengerti, sehingga menimbulkan apersepsi.

Validitas butir soal instrumen penilaian angket dengan menggunakan $r$ tabel sebesar 0,361 dengan nilai signifikansi 0,05 . Hasil uji validitasnya dapat dilihat pada Tabel 3 .

Tabel 3. Hasil Uji Validitas Instrumen

\begin{tabular}{lcccc}
\multicolumn{4}{c}{ Angket } \\
\hline Instrumen Jumlah Valid Tidak \\
\end{tabular}


Data tabel 3 menunjukkan bahwa instrumen angket 25 soal yang diujicobakan tersebut valid, akan tetapi ada beberapa revisi soal masukan dari validator, terutama pada beberapa kalimat yang menimbulkan apersepsi, sehingga kalimat angket kurang dipahami. Setelah direvisi angket digunakan untuk mengambil data kembali.

Hasil reliabilitas instrumen angket 25 soal yang diujicobakan dihasilkan angka reliabilitas 0,995 , dengan kriteria sangat tinggi, sehingga instrumen sudah memenuhi syarat untuk digunakan dalam mengambil data.

Pengambilan sampel secara Random dan purposiv sampling terwakili oleh 110 orang ibu hamil anemia gizi, terdiri dari Puskesmas Nguter (20 orang), Puskesmas Sukoharjo (40 orang), Puskesmas Weru (35 orang), Puskesmas Tawangsari (15 orang). Kriteria inklusi sampel yang diambil, datanya sudah ditentukan yaitu ibu hamil yang teridentifikasi anemia gizi dengan kadar $\mathrm{Hb}<11 \mathrm{~g} / \mathrm{dl}$. Ada beberapa kendala yang dialami pada saat pengambilan data purpusive random sampling antara lain 1). Beberapa ibu hamil sudah ada yang melahirkan, 2) Sumber informasi di lapangan kurang maksimal, 3) Sulit dijangkaunya lokasi sampel, karena jauh, 4) Keterbatasan waktu dan tenaga tim peneliti, sehingga data angket purpusive diambil secara acak. Data grafik yang terlihat pada Gambar 2, adalah data prosentase ibu hamil anemia gizi di wilayah masing-masing dari jumlah populasi terjangkau 110 orang yang ada. Puskesmas Nguter 18,2\%, Puskesmas Sukoharjo 36,4\%, Puskesmas Weru 31,8\% dan Puskesmas Tawangsari 13,6\%. Data tersebut adalah data kasar yang diperoleh di lapangan. Wilayah dengan prosentase pasien ibu hamil anemia gizi sedikit, beberapa disebabkan karena kurangnya data informasi di lapangan.
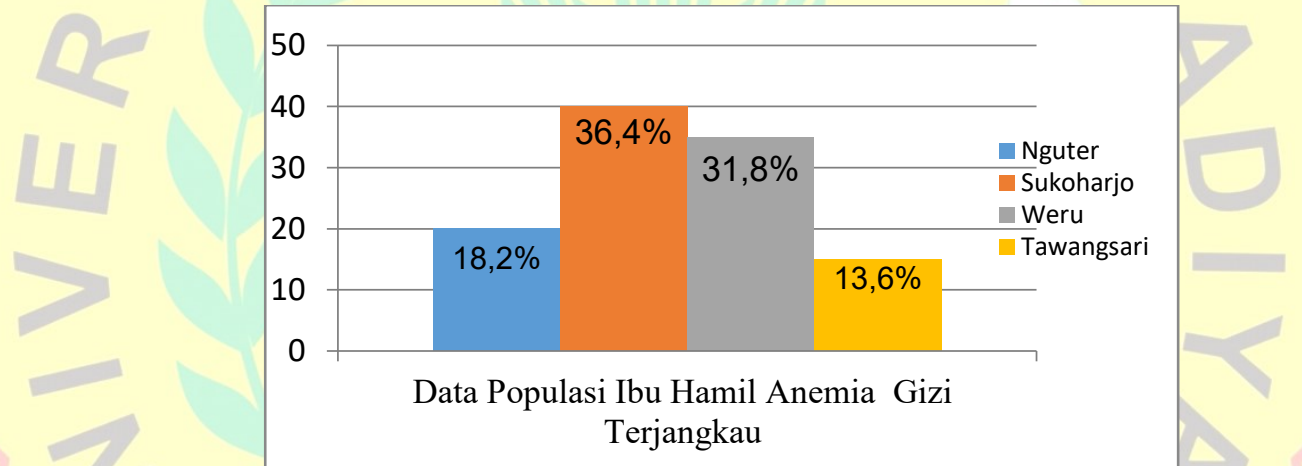

Gambar 2 Histogram Data Random dan purposiv sampling Ibu Hamil Anemia Gizi

Teknik pengambilan data random sampling, sampel diambil dari kelas ibu hamil yang dilakukan di masing-masing Puskesmas pada minggu pertama atau minggu kedua, jumlah peserta ibu hamil dalam satu kelas antara $10-15$ orang. Sampel diambil dari 4 desa pada masing-masing wilayah Puskesmas Nguter, Sukoharjo, Weru dan Tawangsari. Populasi kelas ibu hamil yang diambil 165 orang, dan sampel ibu hamil anemia gizi sebanyak 39 orang, jumlah sudah terdata pada Histogram Gambar 2 Jumlah minimal sampel angket yang dianalisis untuk mengetahui faktorfaktor yang berpengaruh pada ibu hamil anemia gizi adalah 86, diambil dari kelas ibu hamil random sampling 39 orang dan purposiv 47 orang.
Gambar 3 Histogram data Puskesmas Nguter, menjelaskan definisi operasional dari keseluruhan populasi ibu hamil melalui angket secara purpusive dan random sampling wilayah Puskesmas Nguter, meliputi data pasien anemia, resti, paritas, umur kehamilan ibu, usia menikah, dan status kegiatan ibu, dengan keterangan sebagai berikut; (X1): $\mathrm{Hb}<11 \mathrm{~g} / \mathrm{dl}$ (Anemia), (X2): $\mathrm{Hb} \geq 11 \mathrm{~g} / \mathrm{dl}$, (X3):Umur Ibu $<$ 20 th dan $>35$ th(resti), (X4): Umur Ibu 20 th35 th, (X5): Umur Kehamilan < 26 minggu (Resti), (X6): Umur Kehamilan $\geq 26$ minggu, (X7): Paritas: $\geq 4 \mathrm{x}$ : Resti, (X8): Paritas $<4 \mathrm{x}$, (X9): Ibu Rumha Tangga, (X10): IRT dengan Kesibukan lain, (X11): Usia Menikah <20th dan $>$ 35th, (X12): Usia Menikah 20-35th. 


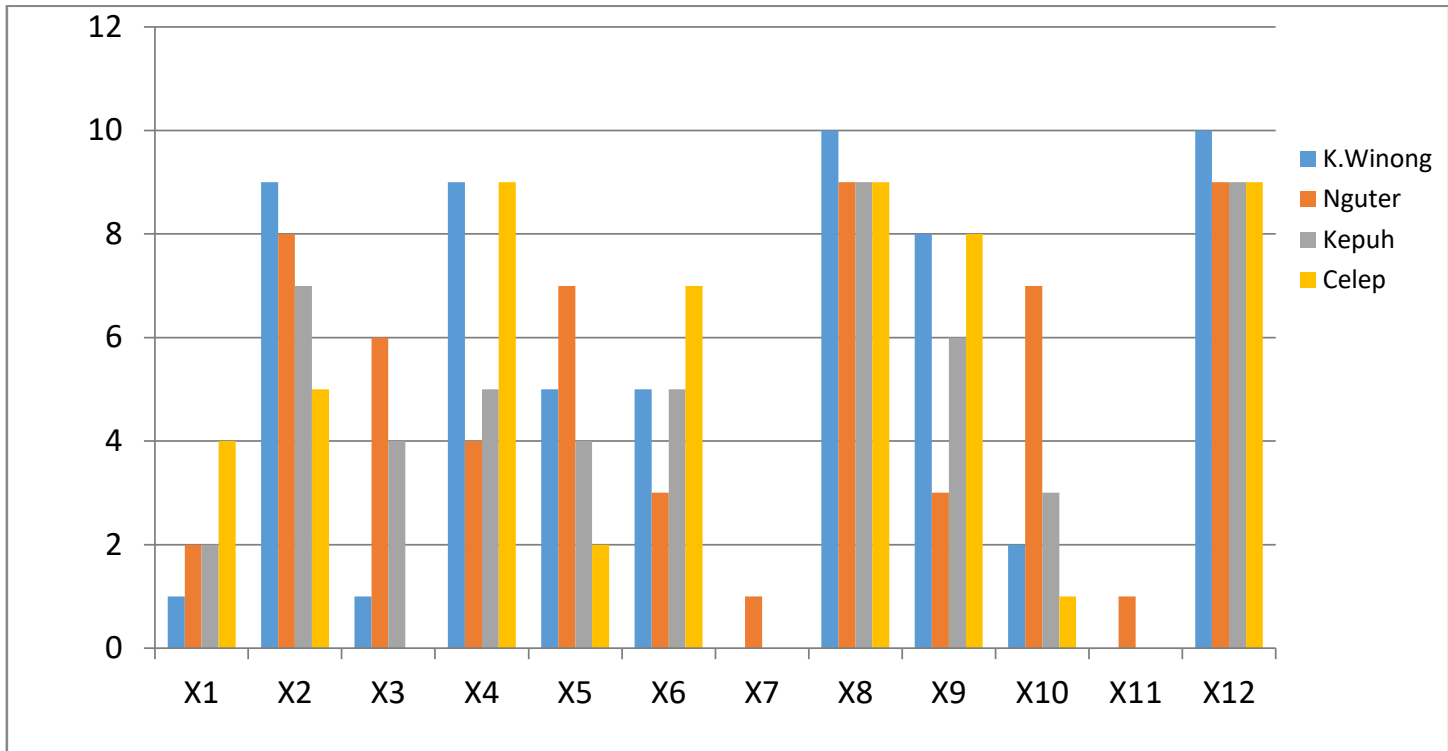

Gambar 3 Histogram Data Puskesmas Nguter

Gambaran dari penjelasan Gambar 3 dengan $\mathrm{Hb}<11 \mathrm{~g} / \mathrm{dl}\left(\mathrm{x}_{1}\right)$, dan umur ibu hamil Histogram diatas, lebih jelas dengan melihat resiko tinggi $<20$ th dan $>35$ th $\left(\mathrm{x}_{3}\right)$ di

Gambar 4 dan 5 data ibu hamil anemia gizi Puskesmas Nguter di bawah ini.

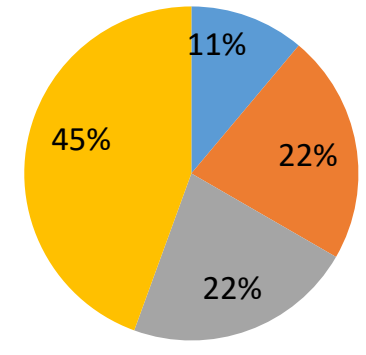

K. Winong

Nguter

Kepuh

Celep

Gambar 4. Diagram Data Ibu Hamil Anemia Gizi Puskesmas Nguter

Gambar 5 Diagram Data Ibu Hamil dengan Umur Resti Puskesmas Nguter 


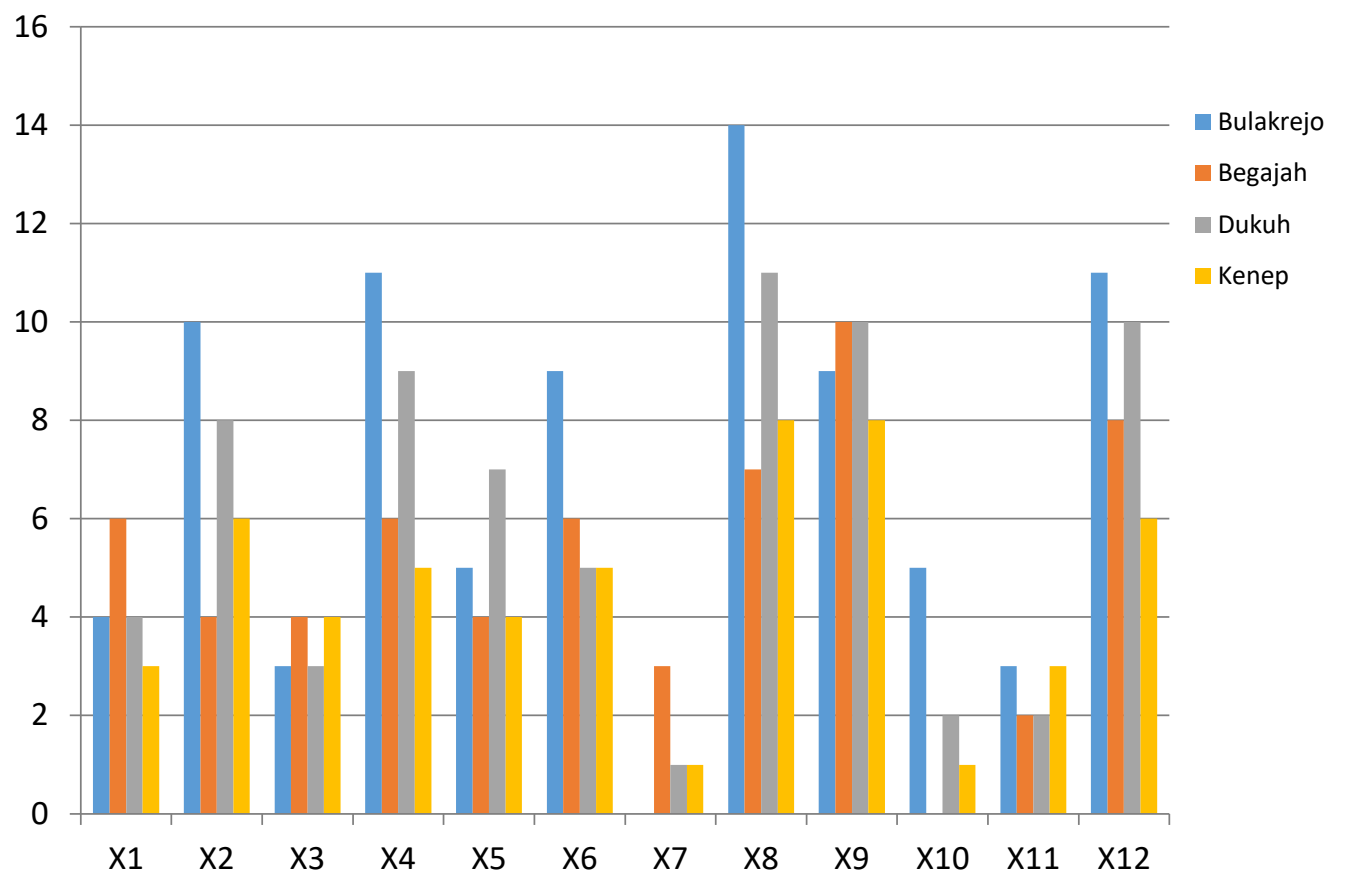

Gambar 6 Histogram Data Puskesmas Sukoharjo

Gambaran dari penjelasan Gambar 6 dengan $\mathrm{Hb}<11 \mathrm{~g} / \mathrm{dl}\left(\mathrm{x}_{1}\right)$, dan umur ibu hamil Histogram diatas, lebih jelas dengan melihat resiko tinggi $<20$ th dan $>35$ th $\left(\mathrm{x}_{3}\right)$, di Gambar 7 dan 8 data ibu hamil anemia gizi Puskesmas Sukoharjo di bawah ini.

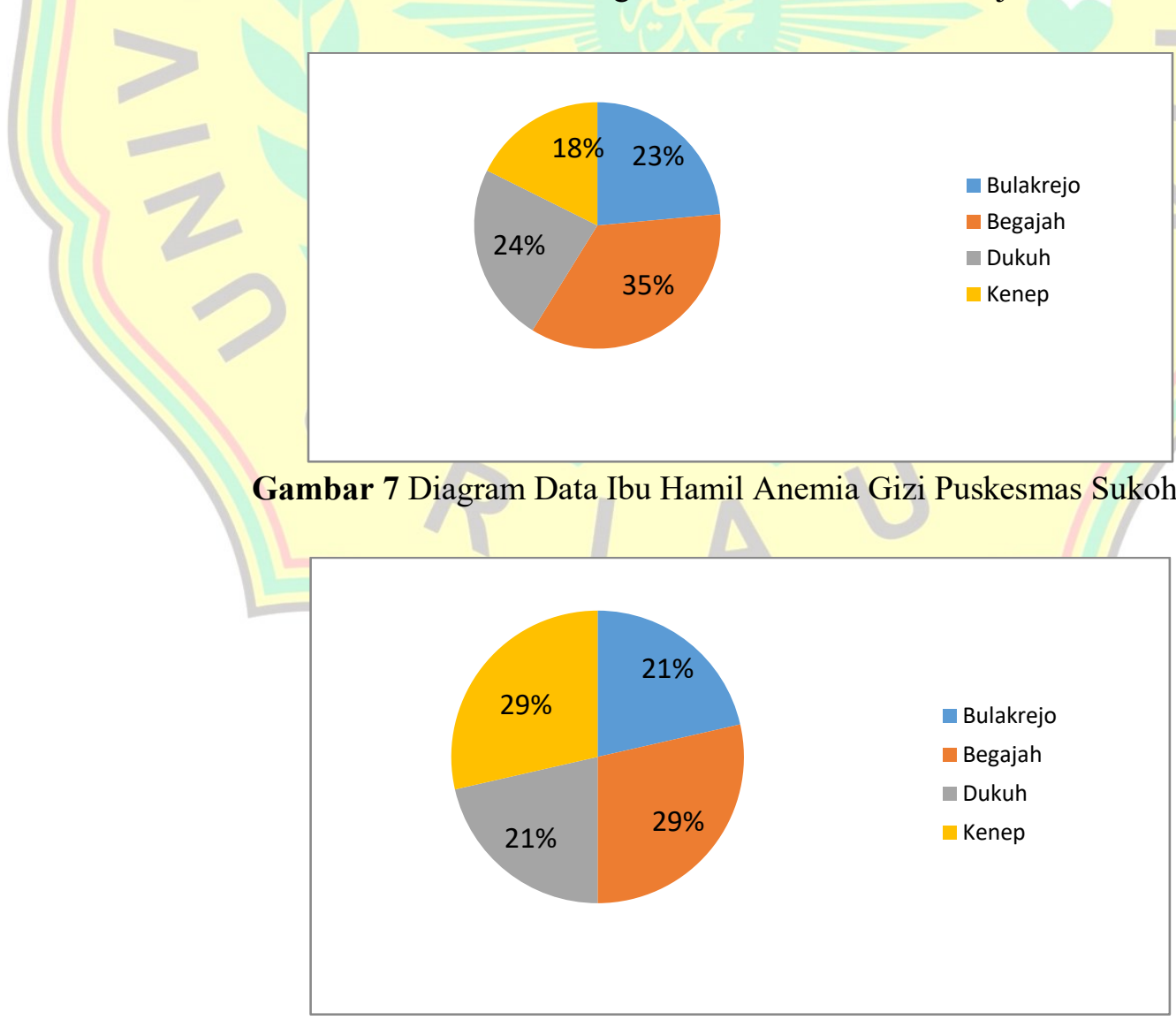

Gambar 8 Diagram Data Ibu Hamil dengan Umur Resti Puskesmas Sukoharjo 


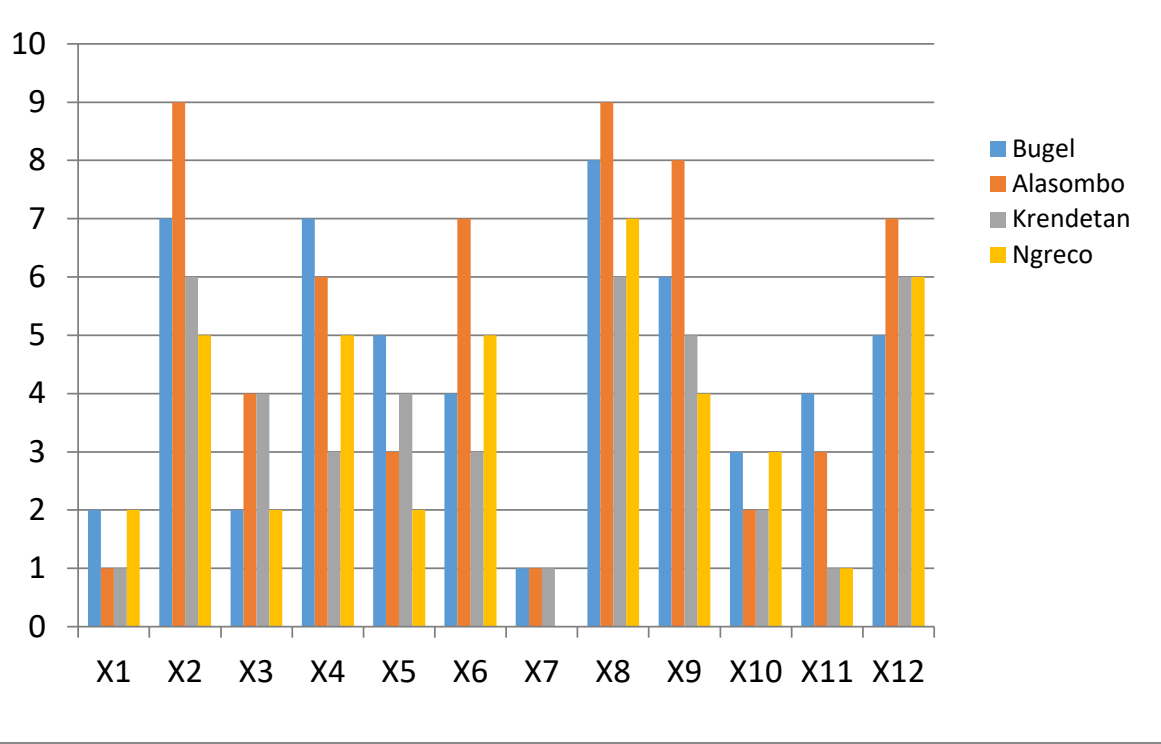

Gambar 9 Histogram Data Puskesmas Weru

Gambaran dari penjelasan Gambar 9 dengan $\mathrm{Hb}<11 \mathrm{~g} / \mathrm{dl}\left(\mathrm{x}_{1}\right)$, dan umur ibu hamil Histogram diatas, lebih jelas dengan melihat Gambar 10 dan 11 data ibu hamil anemia gizi resiko tinggi $<20$ th dan $>35$ th $\left(\mathrm{x}_{3}\right)$, di Puskesmas Weru di bawah ini.

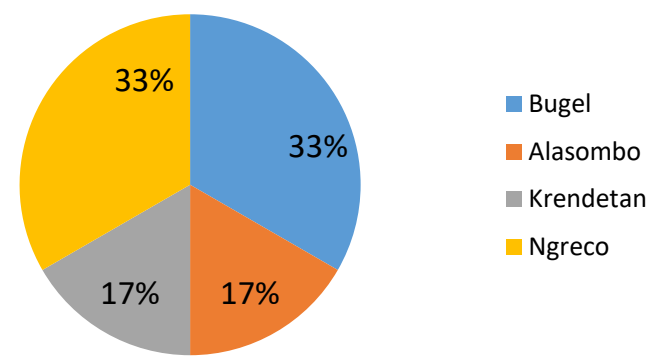

Gambar 10 Diagram Data Ibu Hamil Anemia Gizi Puskesmas Weru

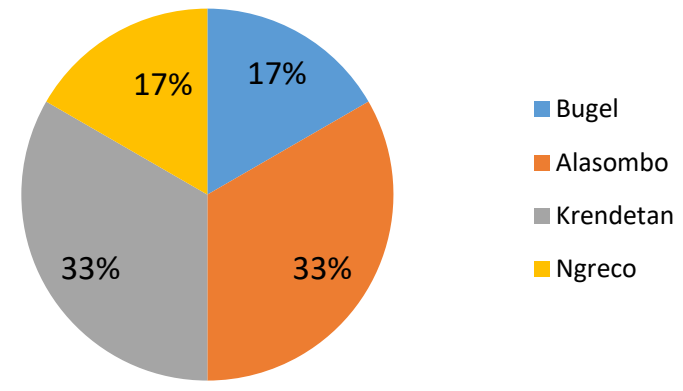

Gambar 11 Diagram Data Ibu Hamil dengan Umur Resti Puskesmas Weru 


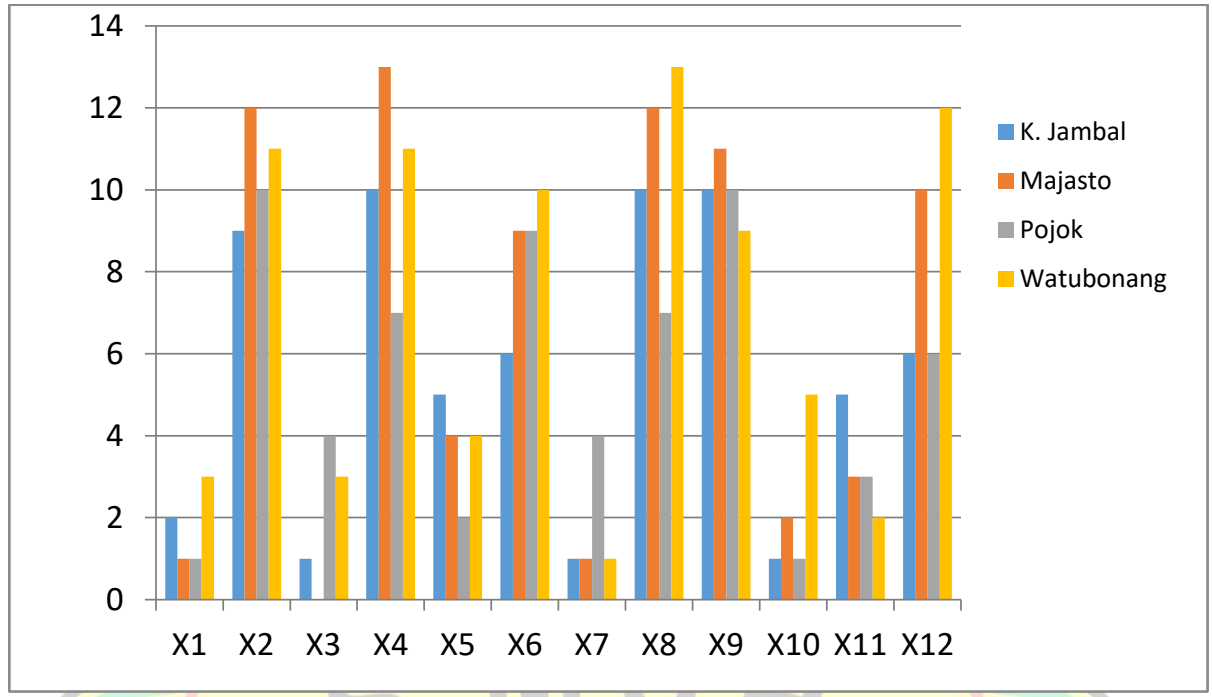

Gambar 12 Histogram Data Puskesmas Tawangsari

Gambaran dari penjelasan Gambar 12 dengan $\mathrm{Hb}<11 \mathrm{~g} / \mathrm{dl}\left(\mathrm{x}_{1}\right)$, dan umur ibu hamil Histogram diatas, lebih jelas dengan melihat resiko tinggi $<20$ th dan $>35$ th $\left(\mathrm{x}_{3}\right)$, di

Gambar 13 dan 14 data ibu hamil anemia gizi Puskesmas Tawangsari di bawah ini.
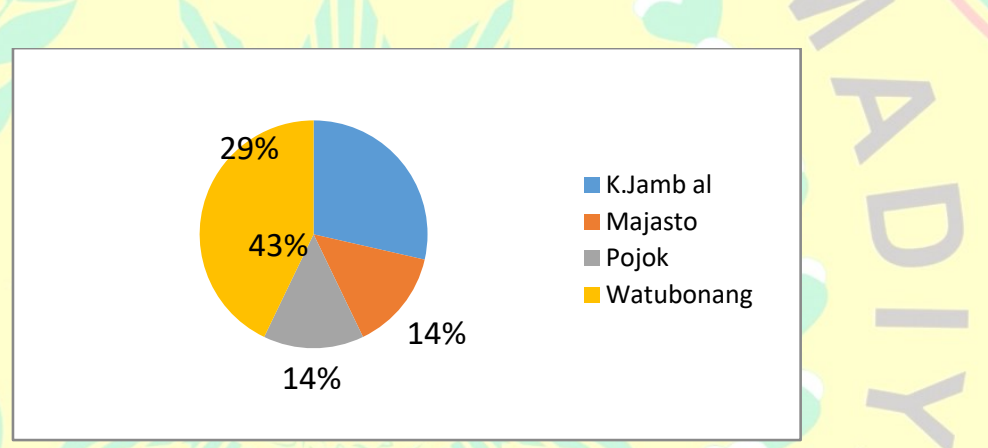

Gambar 13 Diagram Data Ibu Hamil Anemia Gizi Puskesmas Tawangsari

Gambar 14 Diagram Data Ibu Hamil dengan Umur Resti Puskesmas Tawangsari

Pada penelitian yang dilakukan Sitti Asyirah (2012), ibu hamil yang mengalami anemia pada umur $<20$ dan $>35$ Tahun ada 38 (38,0\%), sedangkan yang berumur 20-35 tahun ada $44(44,0 \%)$, hasil uji statistik menunjukkan tidak ada hubungan yang signifikan antara umur dengan kejadian anemia. Sedangkan untuk status gizi ibu hamil dilihat dari hasil pengukuran antropometri LILA (Lingkar Lengan Atas). Meskipun porporsi ibu hamil dengan status gizi kurang ada $57(57,0 \%)$ yang mengalami anemia, tetapi hasil uji statistik dengan chi square menunjukkan tidak ada hubungan yang bermakna antara status gizi dengan anemia. 
Hasil uji tes homogenitas varians Puskesmas Nguter di dapatkan nilai probabilitas (p) $0,000<0,05$, yang berarti varians data homogen, dan uji One Way Anova dengan nilai probabilitas (p) $0,000<0,05$, data tersebut terdistribusi normal, yang berarti secara simultan terdapat pengaruh yang signifikan. Analisis dilanjutkan dengan uji Post Hoc Tukey HSD/ Post Hoc Bonferroni, untuk mengetahui faktor-faktor apa saja yang saling berpengaruh pada masing-masing indikator; diantaranya faktor pengetahuan nutrisi (a), faktor budaya/adat (b), faktor ekonomi (c), faktor dukungan keluarga (d), faktor pengambilan keputusan (e). Dari uji Post Hoc Tukey HSD Puskesmas Nguter menunjukkan ada beda signifikan antara ac, ad, ae, bc, bd, be, ce dan de, dengan nilai signifikansi $<0,05$, sehingga disimpulkan ada pengaruh. Sedangkan antara ab dan cd, menunjukkan nilai signifikansi $>0,05$, tidak ada beda signifikan, sehingga tidak memberikan pengaruh.

Hasil uji tes homogenitas varians Puskesmas Sukoharjo di dapatkan nilai probabilitas (p) $0,000<0,05$, yang berarti varians data homogen, dan uji One Way Anova dengan nilai probabilitas (p) $0,000<0,05$, data tersebut terdistribusi normal, yang berarti secara simultan terdapat pengaruh yang signifikan. Analisis dilanjutkan dengan uji Post Hoc Tukey HSD/ Post Hoc Bonferroni. Data Puskesmas Sukoharjo menunjukkan ada beda signifikan antara ab, ac, ad, ae, bc, bd, be,ce dan de, dengan nilai signifikansi $<0,05$, sehingga disimpulkan ada pengaruh. Sedangkan antara cd, menunjukkan nilai signifikansi $>0,05$, tidak ada beda signifikan, sehingga tidak memberikan pengaruh.

Hasil uji tes homogenitas varians Puskesmas Weru di dapatkan nilai probabilitas (p) $0,05 \leq 0,05$, yang berarti varians data homogen, dan uji One Way Anova dengan nilai probabilitas (p) $0,000<0,05$, data tersebut terdistribusi normal, yang berarti secara simultan terdapat pengaruh yang signifikan. Analisis dilanjutkan dengan uji Post Hoc Tukey HSD/ Post Hoc Bonferroni. Data Puskesmas Weru menunjukkan ada beda signifikan antara ab, ac, ad, ae, bc, bd, be,ce dan de, dengan nilai signifikansi $<0,05$, sehingga disimpulkan ada pengaruh. Sedangkan antara cd, menunjukkan nilai signifikansi $>0,05$, tidak ada beda signifikan, sehingga tidak memberikan pengaruh.

Hasil uji tes homogenitas varians Puskesmas Tawangsari di dapatkan nilai probabilitas (p) $0,05 \leq 0,05$, yang berarti varians data homogen, dan uji One Way Anova dengan nilai probabilitas (p) $0,000<0,05$, data tersebut terdistribusi normal, yang berarti secara simultan terdapat pengaruh yang signifikan. Analisis dilanjutkan dengan uji Post Hoc Tukey HSD/ Post Hoc Bonferroni. Data Puskesmas Tawangsari menunjukkan ada beda signifikan antara ab, ac, ad, ae, bc, bd, be, dan ce, dengan nilai signifikansi $<0,05$, sehingga disimpulkan ada pengaruh. Sedangkan antara cd dan ed menunjukkan nilai signifikansi > 0,05 , tidak ada beda signifikan, sehingga tidak memberikan pengaruh.

Kesimpulan dari uji One Way Anova di ke empat Puskesmas wilayah Kabupaten Sukoharjo, diantara indikator faktor pengetahuan nutrisi, faktor budaya/adat, faktor ekonomi, faktor dukungan keluarga, faktor pengambilan keputusan, secara simultan memberikan pengaruh yang signifikan. Gambar 15 berikut adalah histogram prosentase pengaruh masing-masing faktor terhadap ibu hamil anemia gizi di Puskesmas Nguter. 


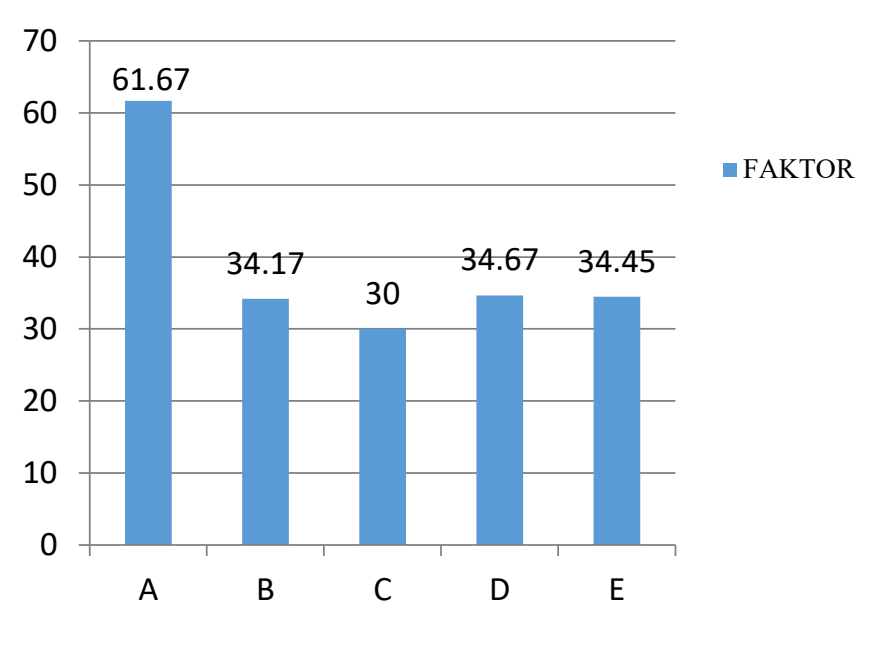

Gambar 15 Histogram prosentase pengaruh masing-masing faktor di Puskesmas Nguter.

Faktor kurangnya pengetahuan nutrisi $61,67 \%$ (a), faktor kurangnya dukungan keluarga/peran suami dalam penyediaan nutrisi adekuat $34,67 \%$ (d), faktor pengambilan keputusan, bias gender dan penanggung jawab keuangan dalam keluarga adalah suami/mertua sebanyak 34,45\% (e), prosentase pengaruh budaya/adat, diantaranya karena mitos/budaya berpantang makanan, menikah diusia muda dan jarak kehamilan yang cukup dekat dengan prosentase $34,27 \%$ (b) dan faktor ekonomi karena pendapatan serta banyaknya anggota keluarga sebanyak $30 \%$ (c). Bila disimpulkan ke dalam simbol prosentase faktor dari tinggi ke rendah di puskesmas Nguter adalah a,d,e,b,c.

Gambar 16 berikut adalah histogram prosentase pengaruh masing-masing faktor terhadap ibu hamil anemia gizi di Puskesmas Sukoharjo.

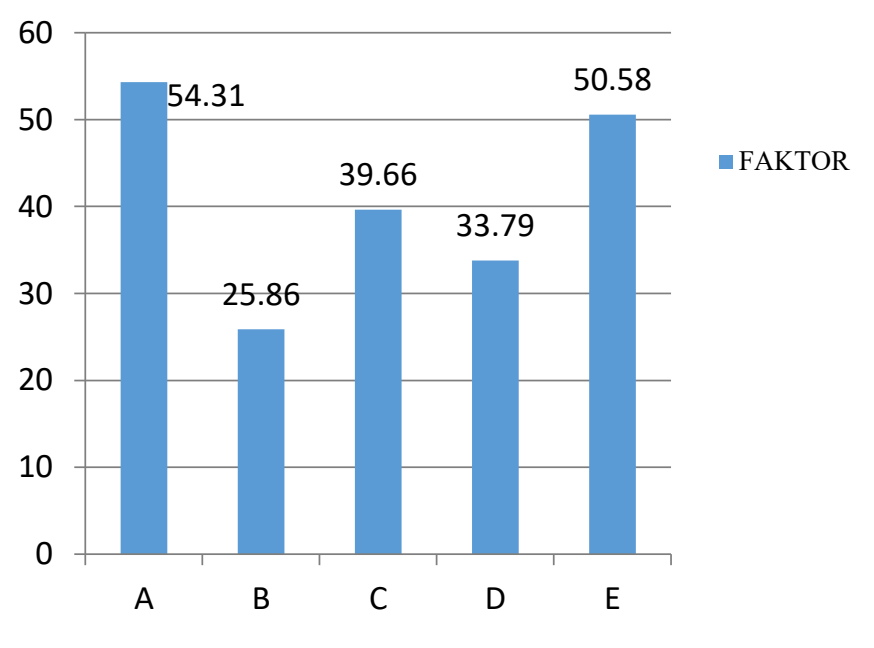

Gambar 16 Histogram prosentase pengaruh masing-masing faktor di Puskesmas Sukoharjo.

Faktor kurangnya pengetahuan nutrisi $54,31 \%$ (a), faktor pengambilan keputusan, bias gender dan penanggung jawab keuangan dalam keluarga adalah suami/mertua sebanyak $50,58 \%$ (e), faktor ekonomi karena pendapatan serta banyaknya anggota keluarga sebanyak
$39,66 \% \quad$ (c), kurangnya dukungan keluarga/peran suami dalam penyediaan nutrisi adekuat $33,79 \%$ (d), dan prosentase pengaruh budaya/adat, diantaranya karena mitos/budaya berpantang makanan, menikah diusia muda dan jarak kehamilan yang cukup dekat dengan 
prosentase 25,86\% (b). Bila disimpulkan ke dalam simbol prosentase faktor dari tinggi ke rendah di puskesmas Sukoharjo adalah a,e,c,d,b.
Gambar 17 berikut adalah histogram prosentase pengaruh masing-masing faktor terhadap ibu hamil anemia gizi di Puskesmas Weru.

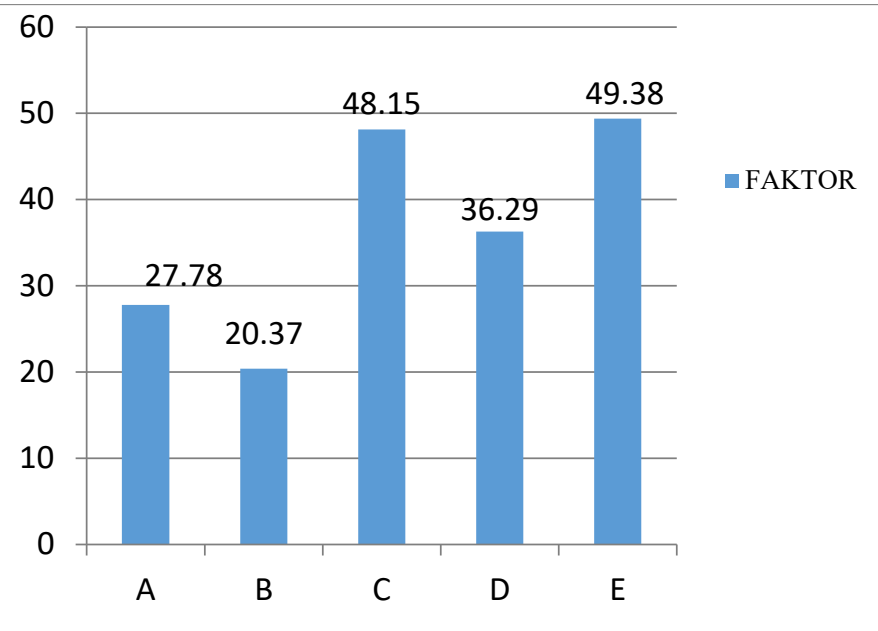

Gambar 17 Histogram prosentase pengaruh masing-masing faktor di Puskesmas Weru

Faktor pengambilan keputusan, bias gender dan penanggung jawab keuangan dalam keluarga adalah suami/mertua sebanyak 49,38\% (e), faktor ekonomi karena pendapatan, serta banyaknya anggota keluarga sebanyak $48,15 \% \quad$ (c), kurangnya dukungan keluarga/peran suami dalam penyediaan nutrisi adekuat $36,29 \%$ (d), kurangnya pengetahuan nutrisi $27,78 \%$ (a), dan prosentase pengaruh budaya/adat, diantaranya karena mitos/budaya berpantang makanan, menikah diusia muda dan jarak kehamilan yang cukup dekat dengan prosentase $20,37 \%$ (b). Bila disimpulkan ke dalam simbol prosentase faktor dari tinggi ke rendah di puskesmas Weru adalah e,c,d,a,b

Gambar 18 berikut adalah histogram prosentase pengaruh masing-masing faktor terhadap ibu hamil anemia gizi di Puskesmas Tawangsari.

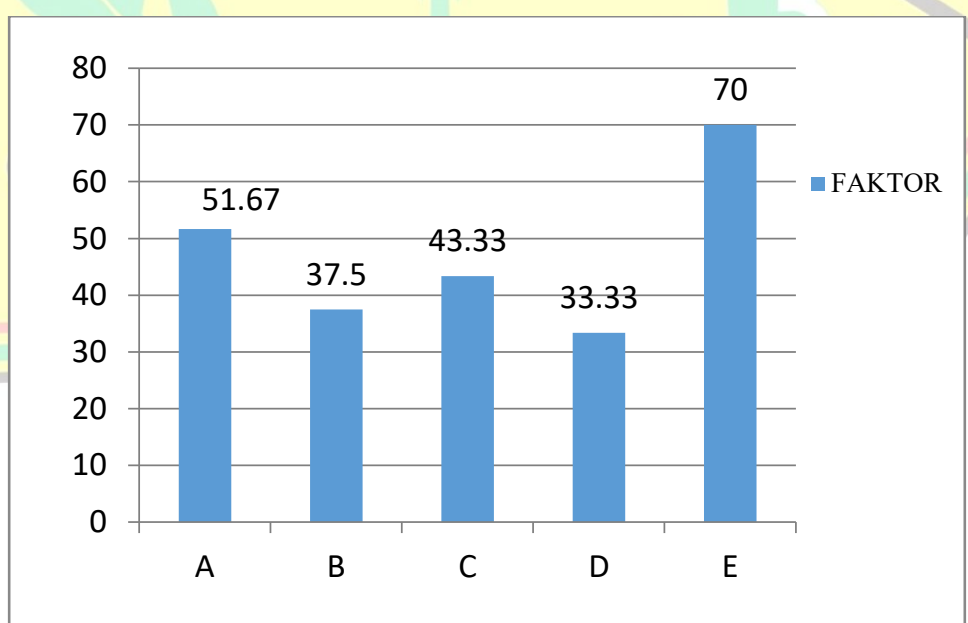

Gambar 18 Histogram prosentase pengaruh masing-masing faktor di Puskesmas Tawangsari

Faktor pengambilan keputusan, bias gender dan penanggung jawab keuangan dalam keluarga adalah suami/mertua sebanyak $70,00 \%$ (e), faktor kurangnya pengetahuan nutrisi 51,67\% (a), ekonomi karena pendapatan, serta banyaknya anggota keluarga sebanyak $43,33 \%$ (c), prosentase pengaruh budaya/adat, diantaranya karena mitos/budaya berpantang 
makanan, menikah diusia muda dan jarak kehamilan yang cukup dekat dengan prosentase $37,50 \%$ (b), dan kurangnya dukungan keluarga/peran suami dalam penyediaan nutrisi adekuat 33,33\% (d). Bila disimpulkan ke dalam simbol prosentase faktor dari tinggi ke rendah di puskesmas Weru adalah e,a,c,b,d.

Penelitian sebelumnya meneliti hubungan pola makan terhadap nutrisi ibu hamil dilakukan oleh Zulaikha (2015), dari hasil uji hipotesa ha diterima yang berarti ada hubungan antara pola makan dengan kejadian anemia pada trimester III Mayoritas responden mempunyai pola makan dengan kategori baik
$13 \mathrm{ibu}$ hamil (43,3\%), sedang $15 \mathrm{ibu}$ hamil (50,0\%), kurang $2 \mathrm{ibu}$ hamil (6,7\%). Mayoritas responden $13 \mathrm{ibu}$ hamil $(43,3 \%)$ tidak anemia, $16 \mathrm{ibu}$ hamil anemia ringan $16(53,3 \%), 1 \mathrm{ibu}$ hamil $(3,3 \%)$ anemia sedang dan tidak ada ibu hamil dengan anemia berat.

Data rekap untuk kelima faktor yang secara simultan berpengaruh pada pemenuhan kebutuhan nutrisi ibu hamil anemia gizi di empat puskesmas wilayah kabupaten Sukoharjo, dapat dilihat pada gambar 19. Histogram Rekap Prosentase Faktor di bawah ini.

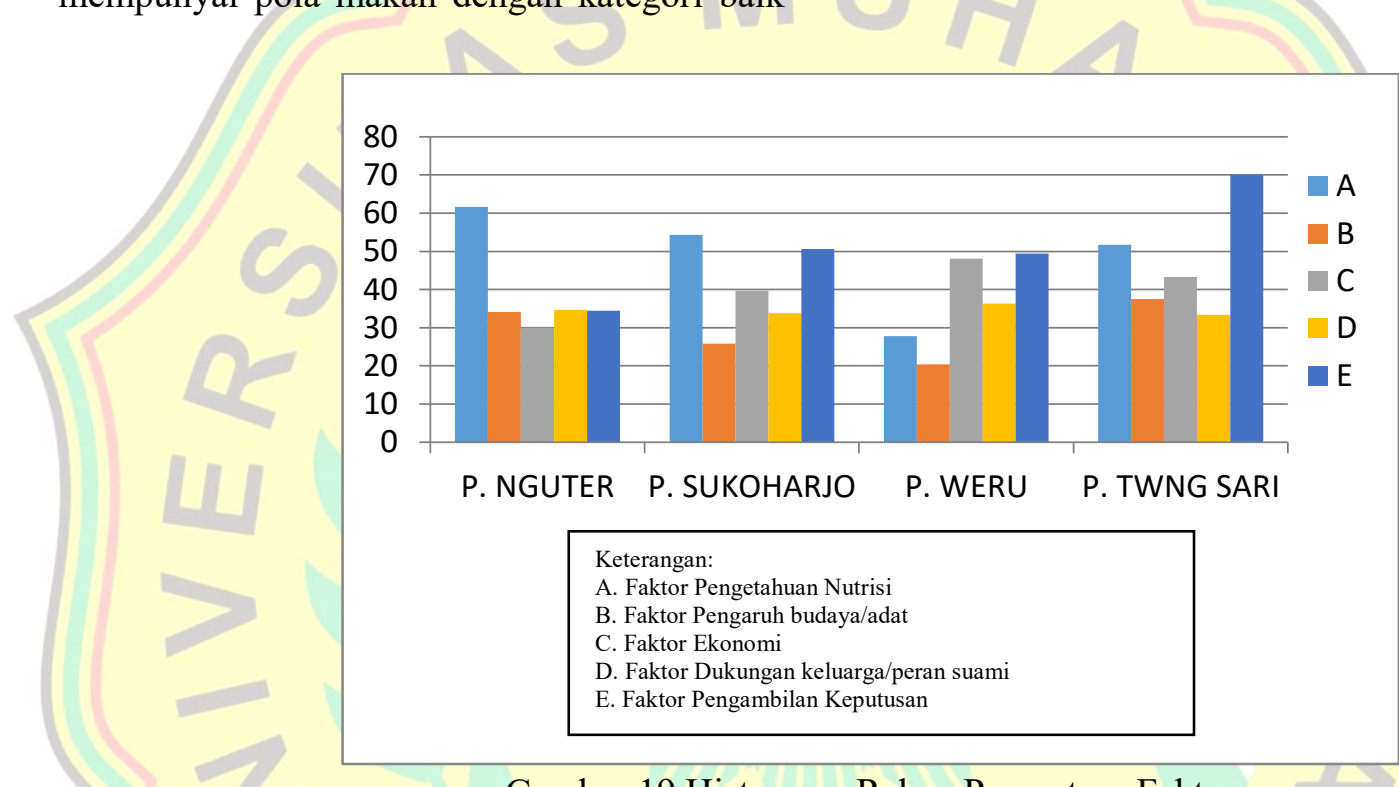

Gambar 19 Histogram Rekap Prosentase Faktor

Pemerintah dan dinas terkait saat ini sudah berusaha memberikan tindak lanjut, dengan diadakannya program kelas ibu hamil, dan penyuluhan, untuk membantu meningkatkan pengetahuan bagi ibu hamil, dalam hal pengetahuan nutrisi, pengetahuan tentang masa kehamilan, pasca melahirkan dan perawatan bayi. Diharapkan program tersebut dapat membantu meningkatkan pengetahuan ibu-ibu hamil di wilayah puskesmas.

Dikutip dari penelitian yang dilakukan Muzaffar, N (2015), dengan judul "Maternal Health and Social Determinants: A Study in Jammu and Kashmir", makanan adalah faktor yang sangat penting yang memiliki dampak pada kesehatan wanita. Seorang wanita yang sehat dapat melahirkan anak yang sehat, dan diet yang seimbang membuat ibu tidak menderita anemia berat. Faktor-faktor sosial juga mempunyai pengaruh yang signifikan pada kesehatan wanita serta janin, diantaranya faktor sosial kesehatan, umur ibu, jarak kelahiran, pengetahuan, tempat tinggal dan pendapatan.Hasil penelitian faktor sosial tersebut, dari setengah wanita di Jammu dan Kashmir 52\% mengalami anemia, 37\% dengan anemia ringan, $13 \%$ dengan anemia sedang, dan $2 \%$ dengan berat. Namun hanya 27,6\% perempuan di Jammu \& Kashmir. Wanita Hindu mempunyai data anemia sangat tinggi karena dari kasta dua terendah.

Penelitian tentang anemia juga dilakukan oleh Melku, M et all (2014), dengan menilai prevalensi dan prediktor anemia ibu dengan 
metode cross-sectional pada 320 wanita hamil, pengambilan data dengan cara wawancara, quesioner, riwayat klinis dan tes laboratorium di RS. Gondar University Ethiopia. Hasil prevalensi anemia adalah $16,6 \%$, mayoritas jenis ringan (64\%) andmorphologically normocytic, anemia normokromik (76\%). Anemia ibu hamil yang tinggi ada pada semster III $918,9 \%$, pendapatan keluarga yang rendah $(3,1 \%)$, jumlah anggota keluarga $4,14 \%$, infeksi cacing tambang $2,72 \%$ dan infeksi HIV 5,75\% adalah prediktor independen dari anemia.

\section{KESIMPULAN}

Penelitian ini menyimpulkan ada pengaruh yang signifikan pada kelima faktor pengambilan keputusan pemenuhan kebutuhan nutrisi ibu hamil anemia gizi, yaitu: 1) faktor pengetahuan/penyediaan nutrisi (Puskesmas Nguter 61,67\%, Sukoharjo 54,31\%, Tawangsari $51,67 \%$, Weru 27,78\%); 2) faktor budaya/adat (Puskesmas Tawangsari 37,5\%, Nguter $34,17 \%$, Sukoharjo 25,86\%, Weru 20,37\%); 3) faktor ekonomi (Puskesmas Weru 48,15\%, Tawangsari 43,33\%, Sukoharjo 39,66\%, Nguter $30 \%$ ); 4) faktor dukungan keluarga (Puskesmas weru $36,29 \%$, Nguter $34,67 \%$, Sukoharjo $33,79 \%$, Tawangsari 33,33\%) dan 5) faktor pengambilan keputusan Puskesmas Tawangsari $70 \%$, Sukoharjo 50,58\%, Weru 49,38\% dan Nguter $34,45 \%$.

\section{DAFTAR PUSTAKA}

Arikunto, S. 2005. Dasar-Dasar Evaluasi Pendidikan. Jakarta: Bumi Aksara.

Citrakesumawati. 2012. Anemia Gizi Masalah dan Pencegahannya.Yogjakarta: Kalika

Dharma K. 2011. Metodologi Penelitian Keperawatan. Jakarta: Trans Info Medika
Depkes RI. 2005. Masalah Gizi di Indonesia dan Penggulangan Anemia di Indonesia, Pedoman Kerja Puskesmas.

Gregory, RJ. 2007. Psychological testing: History, Principles, and pplications. ${ }^{5}$ th Edition. Boston, MA: Allyn dan Bacon.

Melku, M, Addis, Z, Alem,M and Enawgaw, B. 2014. Prevalense and Predictors of Maternal Anemia During Pregnancy in Gondar, Northwest Ethiopia:An Institutional bsed Cross-Sectional study. Hindawi publising Corporation. Volume article ID 108593, 9 pages. http:// dx.doi.org/10.1155/2014/108593.

Muzaffar, N. 2015. Maternal Health and Social Determinants: A Study in Jammu and Kashmir. Public Health Research 2015, 5(5):144-152. DOI:10.5923/j.phr. 20150505.04

Notoatmodjo S. 2010. Metodologi Penelitian Kesehatan. Jakarta: Rineka

Sitti Asyirah. 2012. Faktor-Faktor Yang Berhubungan Dengan Anemia Pada Ibu Hamil di Wilayah Kerja Puskesmas Bajeng Kecamatan Bajeng Kabupaten Gowa. Universitas Indonesia. Skripsi.

WHO. 2008. Wordwide Prevalence of Anemia 1993-2005. Http:/Whq Libdoc. Who.Int/publications/2008/978924 1596657eng.pdf

Zulaikha, E. 2015. Hubungan Pola Makan Dengan Kejadian Anemia Pada Ibu Hamil Trisemester III di Puskesmas Pleret Bantul. Stikes Aisyah Yogyakarta. KTI 